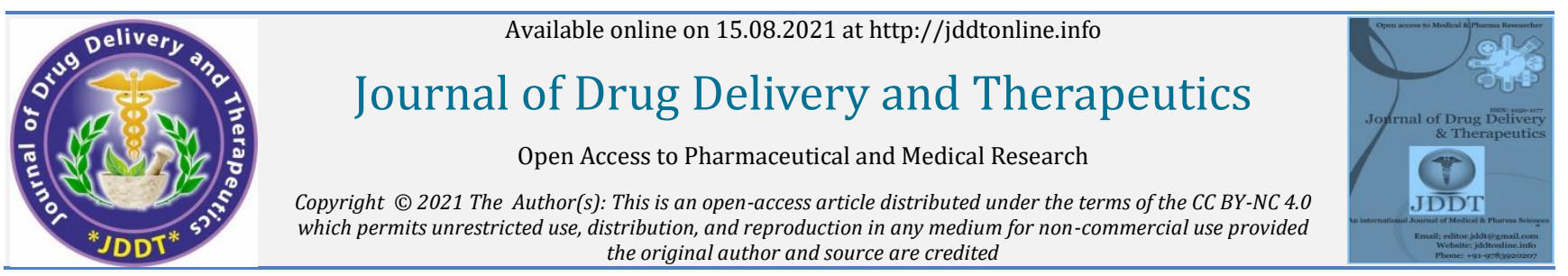

Open Access Full Text Article the original author and source are credited

Review Article

\title{
A Review on the Novel Corona Virus with International and Indian Perspective
}

Gayatri Suresh K P*, Thabit Ahmed**, Mohamed Abdelgadir Mohammed Saeed*, Jereish Varghese Daivamthadathil*, Anandhu Jayan***, Jerin Reji Samuel***

*PharmD Interns, Bangalore Baptist Hospital, Bellary road, Bangalore, Karnataka, India

**Cardiologist, Consultant, Bangalore Baptist Hospital, Bellary road, Bangalore, Karnataka, India

***PharmD students, Bangalore Baptist Hospital, Bellary road, Bangalore, Karnataka, India

\section{Article Info:}

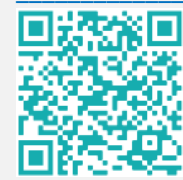

\section{Article History:}

Received 11 June 2021

Reviewed 18 July 2021

Accepted 27 July 2021

Published 15 August 2021

\section{Cite this article as:}

K P GS, Ahmed T, Mohammed Saeed MA Daivamthadathil JV, Jayan A, Samuel JR, A Review on the Novel Corona Virus with International and Indian Perspective, Journal of Drug Delivery and Therapeutics. 2021; 11(4-S):236-241

DOI: http://dx.doi.org/10.22270/jddt.v11i4-S.4954

\section{Abstract}

On 31 December 2019, pneumonia of unknown cause was detected in Wuhan, China, and was first reported to the WHO Country Office in China. On 30 January 2020, the outbreak was declared a Public Health Emergency of International Concern. ${ }^{1}$

It was an outbreak of severe acute respiratory syndrome corona virus 2 (SARS-CoV-2) infection that occurred in Wuhan, Hubei Province, China and got spread across China and beyond. WHO officially named the disease - Corona virus Disease 2019 (COVID-19) on February 12, 2020. ${ }^{2}$

It has been spreading worldwide for a period of atleast a year \& half ${ }^{3}$ This review article addresses the current scenario caused by the SARS- Co V along with the treatment protocols and ongoing vaccines.

Keywords: Corona virus,COVID-19, m RNA, current therapy, vaccines, clinical symptoms, review

*Address for Correspondence:

Dr Gayatri Suresh K P, Bangalore Baptist Hospital, Bellary road, Bangalore, Karnataka, India

\section{Introduction}

\section{Common flu and Covid 19}

Corona viruses as the name suggests are called so due to the crown-like projections on their surfaces. "Corona" in Latin means "halo" or "crown." first identified in the 1960s, followed by SARS-Co V IN 2003, HCo V- NL63 in 2004, HKU1 in 2005, MERS-CoV in 2012 respectively. The human corona viruses are currently classified into seven types, which include, HCoV-229E, HCoV-OC43, HCoV-NL63, SARS-CoV, HKU1, MERS-CoV and 2019-nCoV. The corona virus (MERS$\mathrm{CoV}$ and SARS-CoV) are more dangerous among all the coronaviruses. 4 COVID-19 and influenza have a similar clinical presentation since they both cause respiratory disease and primarily both viruses are transmitted by contact, droplets and fomites ${ }^{5} 6$

\section{SARS CoV-2}

Corona viruses have naturally and evolutionarily, shaped and hosted by the bats. Indeed, it is postulated that most of the corona viruses that are found in humans are derived from the bat reservoir. ${ }^{7}$ The recent studies have confirmed the genetic similarity of SARS-CoV-2 and a bat beta corona virus of the sub-genus Sarbecovirus. ${ }^{7,8}$

\begin{tabular}{|l|l|l|l|}
\hline SIGNS AND SYMPTOMS & COLD & FLU (INFLUENZA) & COVID-19 (WUHAN CORONA VIRUS) \\
\hline Fever & Mild if present & Often & Often \\
\hline Fatigue, Tiredness & Occasional, mild & Common & Occasional \\
\hline Sneezing & Common & Infrequent & Infrequent \\
\hline Body Aches & Common & Common & Occasional \\
\hline Headache & Very infrequent & Common & Occasional \\
\hline Sore Throat & Common & Occasional & Occasional \\
\hline Stuffy or Runny Nose & Common & Occasional & Infrequent \\
\hline Diarrhoea & No & Occasional & Infrequent \\
\hline Watery eyes & Common & Common & Infrequent \\
\hline Cough & Mild & Dry cough & A dry cough, often severe \\
\hline Shortness of Breath & No & Rare & With mild/moderate infection \\
\hline
\end{tabular}


The genome sequence of the novel corona virus is $96.2 \%$ similar to the bat SARS-related coronavirus (SARSr-CoV; RaTG13) collected from Yunnan province, China, but is not similar to the genomes of SARS-CoV (about 79\%) or MERS$\mathrm{CoV}$ (about 50\%). It is been confirmed that the SARS-CoV-2 uses the same receptor, the angiotensin-converting enzyme II (ACE2), same as that of SARS-CoV. But the route of transmission from natural reservoirs to humans remains blinded, studies have been showing the pangolins providing a partial spike gene to SARS-CoV-2. (the crucial functional sites in the protein of SAR-CoV-2 are identical to one of the viruses that were isolated from a pangolin). 7,9

\section{Aetiology and pathophysiology}

CoVs are positive-stranded RNA viruses that have a spikey appearance due to the presence of glycoproteins on the outer surface. It belongs to the family Coronaviridae, which has the subclass Orthocoronavirinae that classifies the viruses into four genera of CoVs that include Alphacoronavirus (alphaCoV), Betacoronavirus (betaCoV), Deltacoronavirus (deltaCoV), and Gammacoronavirus (gammaCoV). 1011

The SARS-CoV-2 belongs to the betaCoVs category. It has a round/elliptical structure with a pleomorphic form. It has a diameter of $60-140 \mathrm{~nm}$. This novel corona virus is sensitive to ultraviolet rays and heat and also these viruses can get inactivated by lipid solvents that include ether (75\%), ethanol, chlorine-containing disinfectant, peroxyacetic acid and chloroform except for chlorhexidine. ${ }^{10,12}$

\section{Virion structure}

Coronavirus virus mainly contains 4 structural proteins,i.e spike (S), membrane (M), envelope (E), and nucleocapsid (N) proteins, which are all encoded within the $3^{\prime}$ end of the viral genome.

$S$ protein: The S protein with a mass of $\sim 150 \mathrm{kDa}$ uses an $\mathrm{N}$ terminal signal sequence to gain access to the ER and is heavily $\mathrm{N}$-linked glycosylated. The spikey structure on the surface of the virus is due to the encodement of the homotrimers. ${ }^{11,13}$. It is a trimeric S glycoprotein that is a class I fusion protein that mediates the attachment to the host receptor. In some coronaviruses, $\mathrm{S}$ is cleaved by a host cell into two separate polypeptides noted S1 and S2. S1 forms the large receptor-binding domain of the $\mathrm{S}$ protein and S2 forms the stalk of the spike molecule. ${ }^{11}$

M protein: It is small in mass with $\sim 25-30 \mathrm{kDa}$ and has 3 transmembrane domains and is observed to give the virion its shape. 11

E protein: The E protein has a mass of $\sim 8-12 \mathrm{kDa}$ and is found in small quantities. E protein in coronaviruses are specifically different but have a common architecture. The significant topology of E protein is not completely studied but data suggest that it is a transmembrane protein. ${ }^{11}$

Patients infected with COVID-19 had higher leukocyte numbers, high blood levels of cytokines and chemokines, increased levels of plasma pro-inflammatory cytokines and abnormal respiratory findings. The common symptoms included dry cough, coarse breathing sounds of both lungs, body temperature, fever, sore throat and fatigue. ${ }^{14}$

The pathogenesis of COVID-19 infection being a respiratory system targeting virus is considered to be severe pneumonia, RNA anaemia, along with the incidence of ground-glass opacities, and acute cardiac injury. ${ }^{15}$

\section{Clinical presentation and transmission}

\section{Incubation period}

The incubation period for COVID-19 is observed to vary between 7-14 days, with a median time of 4-5 days from exposure to symptoms onset. Certain studies have reported 97.5\% of patients with COVID-19 are developing symptoms within 11.5 days of SARS-CoV-2 infection. ${ }^{16}$

\section{Clinical symptoms}

The prevalence of symptoms of COVID 19, based on over 55,000 lab cases shows fever(88\%), dry cough(67\%),sore throat (14\%) and fatigue(38\%).COVID 19 is more contagious and less severe when compared to other SARS \& MERS. ${ }^{14}$

\section{Implications of mutations on the virus}

Over 1year \& 6 months, 1200 variants of the novel coronavirus have been identified, of which 1000 strains have been studied. ${ }^{17}$ The current scenario rates 11 mutations per sample, which accounts for more than the national average (8.4) and the global average(7.3). ${ }^{18}$

Scientists have observed three major mutations of the COVID-19 virus so far:

\section{- D614G \\ - VUI2020-12/01 \\ - N501Y}

D614G was responsible for the fast spread of the virus in Europe, the US and the rest of the world. VUI 2020-12/01 and N501Y are the current ones spreading in the UK. And the 'South Africa drift', where three mutations happened in the genetic make-up of the virus. ${ }^{19}$ Also, B.1.167 Covid variant being recognised as Singapore strain is believed to affect the younger children. ${ }^{20}$

Currently, the exponential increase of the cases in India is attributed to the mutations -L452R, E484Q, and P681R. with other mutations being recognised over as:

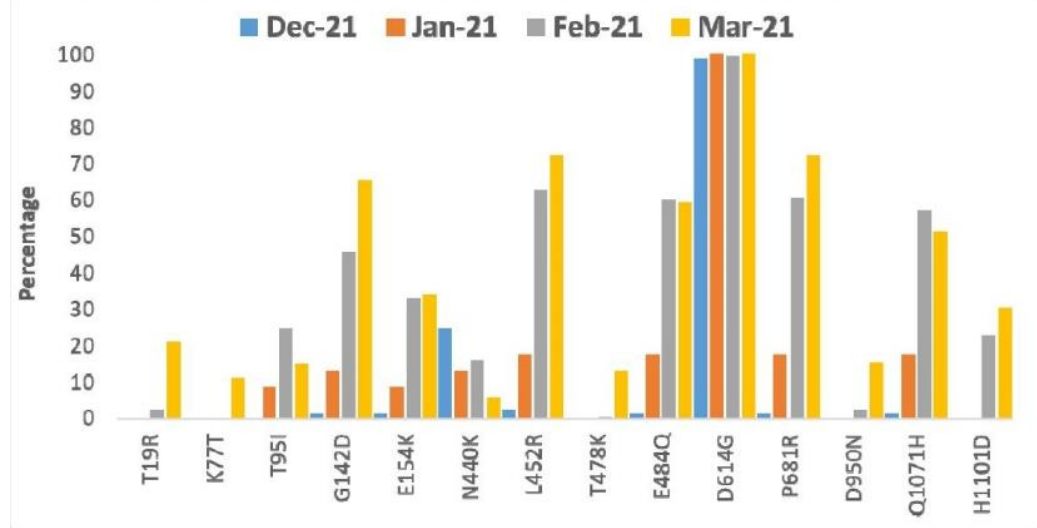


Another variant Delta (B.1.617.2), belongs to a viral lineage first recognised in India during the second wave, that seemed to be around $60 \%$ more transmissible than the already highly infectious Alpha variant (also called B.1.1.7). Delta is found to be partially resistant to vaccines, A study published on 22 May found that a single dose of either AstraZeneca's or Pfizer's vaccine reduced a person's risk of developing COVID-19 symptoms caused by the Delta variant by $33 \%$, compared to $50 \%$ for the Alpha variant. A second dose of the AstraZeneca vaccine boosted protection against Delta to $60 \%$ (compared to $66 \%$ against Alpha), while two doses of Pfizer's jab were $88 \%$ effective (compared to $93 \%$ against Alpha). ${ }^{2122}$

\section{Treatment approaches $\&$ failure}

\section{Lopinavir and Ritonavir}

Lopinavir and ritonavir (Kaletra) was given to those adult patients with laboratory-confirmed SARS-CoV-2 infection with certain criteria were eligible to receive lopinavir/ritonavir for 14 days after being confirmed with (i) respiratory distress with respiratory rate $\geq 22 / \mathrm{min}$ or $\mathrm{SpO}_{2}$ of $<94$ per cent; (ii) lung parenchymal infiltrates on chest X-ray; (iii) hypotension defined as systolic blood pressure $<90 \mathrm{mmHg}$ or need for vasopressor/inotropic medication; (iv) new-onset organ dysfunction, (v) age $>60$ yr, diabetes mellitus, renal failure, chronic lung disease and immune-compromised patients. Patients were monitored to document clinical, laboratory and safety outcomes. ${ }^{23}$

\section{Failure}

In a few of the studies conducted it is concluded that in hospitalized adult patients with severe Covid-19, there was no benefit with lopinavir-ritonavir treatment beyond standard care. 24 Also according to the literature, it states that there was no significance in the treatment of Kaletra with COVID-19, only that there was an improvement of 1 day earlier of recovery. ${ }^{25}$

\section{Tocilizumab}

Recommended the use of tocilizumab as a single intravenous dose of $8 \mathrm{mg} / \mathrm{kg}$ of actual body weight which can be increased up to $800 \mathrm{mg}$ given in combination with dexamethasone ( $6 \mathrm{mg}$ daily)in certain hospitalized patients who are exhibiting rapid respiratory decompensation due to COVID-19.

\section{Failure}

Tocilizumab (Actemra) did not reduce severe respiratory symptoms, intensive care visits, or death any better than standard treatments, the Italian Medicines Agency. ${ }^{26}$

\section{Remdesivir}

recommended using remdesivir for patients who were on high-flow oxygen, mechanical ventilation, or ECMO. ${ }^{27}$

Failure

studies report that in patients with covid 19 who were administered with remdesivir, the patients' developed bradycardia along with signs of worsening QT interval. This reverted upon stopping remdesvir therapy. The prevalence of bradycardia with prolonged QT interval is not well-known yet with this medication. ${ }^{28}$

\section{Ivermectin}

Studies done in vitro suggested that ivermectin acts by inhibiting the host importin alpha/beta-1 nuclear transport proteins, that is a vital intracellular transport process where viruses hijack to enhance infection thereby suppressing the host's antiviral response and also ivermectin acts by interfering with the severe acute respiratory syndrome coronavirus 2 (SARS-CoV-2) spike protein to the human cell membrane. Ivermectin is said to be host-directed based on its broad-spectrum activity in vitro against the viruses that cause other major viral infections. some studies show that ivermectin has a potential anti-inflammatory property, which has been postulated to be beneficial in people with COVID-19.29

\section{Failure}

The small size of the study, the unclear treatment arm assignments, and the lack of accounting of disease severity at baseline make it difficult to conclude the efficacy of using IVM to treat patients with mild COVID-19.30

\section{Current treatment}

\begin{tabular}{|l|l|l|l|}
\hline TREATMENT & DRUGS & DOSES & $\begin{array}{l}\text { SPECIAL } \\
\text { CONSIDERATIONS/FEATURES }\end{array}$ \\
\hline Tab Hydroxychloroquine & $\begin{array}{l}\text { T. HCQ (In high risk patients } \\
- \text { DM / HTN / CVA / CKD / } \\
\text { CLD / Obesity / Age > 60 yrs })\end{array}$ & $\begin{array}{l}\text { Day 1 - 400 mg BD Followed } \\
\text { by } 400 \mathrm{mg} \text { OD x 4 Days }\end{array}$ & $\begin{array}{l}\text { avoid in cardiac disease or if } \\
\text { QTc }>480 \mathrm{~ms}\end{array}$ \\
\hline Antibiotics & Tab Azithromycin & $500 \mathrm{mg}$ OD FOR 5 days & $\begin{array}{l}\text { In case azithromycin is } \\
\text { contraindicated- } \\
\text { T. AmoxClav 625 BD }\end{array}$ \\
& $\begin{array}{l}\text { T. Azithromycin } \\
+ \\
\text { Inj. Piptaz } \\
\text { OR }\end{array}$ & $\begin{array}{l}500 \mathrm{mg} \text { OD x 5 Days } \\
\text { Inj meropenem }\end{array}$ & $\begin{array}{l}\text { In case of suspected secondary } \\
\text { bacterial infection. }\end{array}$ \\
\hline
\end{tabular}




\begin{tabular}{|c|c|c|c|}
\hline Routine & $\begin{array}{l}\text { T. Paracetamol } \\
\text { Anti-tussives } \\
\text { T. Vitamin C } \\
\text { T. Zinc } \\
\text { C. Omeprazole/ } \\
\text { Inj Pantoprazole }\end{array}$ & $\begin{array}{l}500 \mathrm{mg} \\
\text { SOS } \\
500 \mathrm{mg} \mathrm{OD} \\
50 \mathrm{mg} \mathrm{BD} \\
20 \mathrm{mg} \mathrm{BD} / \\
40 \mathrm{mg} \mathrm{OD}\end{array}$ & $\begin{array}{l}\text { With adequate hydration with } \\
\text { conservative fluids. } \\
\text { Oxygen maintenance: Maintain } \\
\text { Target SPo } 2 \text { > } 90 \% \text { NRM (10 - } \\
15 \text { lit / min) } \downarrow \text { HFNC }(10 \text { - } 60 \text { lit } \\
\text { / min) } \downarrow \text { CPAP (TV } 6 \mathrm{ml} / \mathrm{kg} \text {; } \\
\text { PEEP 5-15 cm H20; Target PP } \\
30 \mathrm{~cm} \text { H20) } \downarrow \text { MV (ARDS } \\
\text { Protocol) }\end{array}$ \\
\hline Anticoagulants & Inj enoxaparin & 40 mg SC OD x 5 Days & $\begin{array}{l}\text { can be started as prophylactic } \\
\text { without D DIMER. } \\
\text { Contraindicated in ESRD, active } \\
\text { bleeding, emergency surgery, } \\
\text { platelets }<20,000 / \text { mm3 } 3 \text {, BP > } \\
200 / 120 \text { ) Inj. Dalteparin } 2500 \\
\text { IU SC OD ×5 days }\end{array}$ \\
\hline Monoclonal antibodies & tolicizumab & $\begin{array}{l}400 \mathrm{mg}(\max 800 \mathrm{mg} \text { ) slow } \\
\text { IV in } 100 \mathrm{ml} \mathrm{NS} / 1 \text { Hour }\end{array}$ & $\begin{array}{l}\text { Contra Indications - Active } \\
\text { Infections, TB, Hepatitis, } \\
\text { Platelets }<1 \mathrm{~L} / \mathrm{mm} 3 \text {, ANC }< \\
2000 / \mathrm{mm} 3\end{array}$ \\
\hline Steroids & $\begin{array}{l}\text { Dexamethasone } \\
\text { inj. Methyl Prednisolone }\end{array}$ & $\begin{array}{l}0.1-0.2 \mathrm{mg} / \mathrm{kg} \approx 6 \mathrm{mg} \mathrm{IV} \\
\text { OD } \times 5 \text { Days } \\
1.0-2.0 \mathrm{mg} / \mathrm{kg} \approx 80 \mathrm{mg} \times 10 \\
\text { Days }\end{array}$ & \\
\hline
\end{tabular}

Vaccinations put forward

\begin{tabular}{|c|c|c|c|c|c|}
\hline Vaccine & Type & Manufacturer & Dose & Effectiveness & Storage \\
\hline $\begin{array}{l}\text { Pfizer } \\
\text { (BNT162b2) }\end{array}$ & mRNA vaccine- & $\begin{array}{l}\text { Pfizer, Inc., and } \\
\text { BioNTech }\end{array}$ & $\begin{array}{l}2 \text { shots, } 21 \text { days } \\
\text { apart }\end{array}$ & $\begin{array}{l}95 \% \text { against } 1^{\text {st }} \\
\text { strain. } \\
31\end{array}$ & $2-8^{\circ} \mathrm{C}$ \\
\hline Moderna & mRNA-1273 & ModernaTX, Inc. & $\begin{array}{l}2 \text { shots, one month } \\
\text { (28 days) apart }\end{array}$ & $\begin{array}{l}\text { 92-94.1\% against } 1 \text { st } \\
\text { strain. } 3132\end{array}$ & $\begin{array}{l}2-8^{\circ} \mathrm{C} \text { for upto } \\
\text { 30days. }\end{array}$ \\
\hline $\begin{array}{l}\text { Covaxin } \\
\text { (BBV154) }\end{array}$ & Inactivated virus & $\begin{array}{l}\text { Bharat Biotech's } \\
\text { BSL-3 }\end{array}$ & $\begin{array}{l}2 \text { shots, one month } \\
\text { (28 days) apart. }{ }^{33}\end{array}$ & $\begin{array}{l}81 \% \text { interim efficacy } \\
\text { against } 1^{\text {st }} \text { strain }\end{array}$ & $2-8^{\circ} \mathrm{C}$ \\
\hline $\begin{array}{l}\text { AstraZeneca } \\
\text { (Covishield, } \\
\text { Vaxzevria) }\end{array}$ & Viral vector & Oxford university & $\begin{array}{l}2 \text { shots, 8-12weeks } \\
\text { apart. }\end{array}$ & $\begin{array}{l}79-85 \% \text { against } 1^{\text {st }} \\
\text { strain }\end{array}$ & $\begin{array}{l}2-8^{\circ} \mathrm{C} \text { for } 6 \\
\text { months }\end{array}$ \\
\hline
\end{tabular}

*mRNA vaccines teach our cells how to make a protein-or even just a piece of a protein-that triggers an immune response inside our bodies. 31

Johnson \& Johnson's Janssen COVID-19 Vaccine: CDC and FDA have recommended a pause in the use of Johnson \& Johnson's J\&J/Janssen COVID-19 Vaccine in the United States out of an abundance of caution as people who have received the J\&J/Janssen COVID-19 Vaccine within the past three weeks developed severe headache, abdominal pain, leg pain, or shortness of breath should seek medical care right away. ${ }^{34}$

\section{Vaccination and Incidence of infection}

During the initial implementation phases, as for every new vaccine, post-introduction evaluations will be important to address many of the remaining questions about the performance of these vaccines. When a vaccine is used outside trial populations the effects of the vaccine may differ in specific geographies or subpopulations. Vaccine effectiveness (VE) might be different against various disease outcomes, against infection and infectiousness, and newly emerging virus variant strains. Additionally, important programmatic issues will need to be addressed, such as the effectiveness of incomplete dose schedules, variation in dose intervals, and the interchangeability of different vaccine products. Suboptimal cold chain capacity, and off-schedule and incomplete delivery of doses could lead to different vaccine performances. Vaccines might not be as effective against new variants. Finally, assessing the duration of vaccine protection requires longer-term studies. 35

\section{Complications of Covid 19}

In population about 1 in 6 , have been found to show complications. Many of these complications may be caused by a condition known as cytokine release syndrome or a cytokine storm. This is when an infection triggers your immune system to flood your bloodstream with inflammatory proteins called cytokines. They can kill tissue and damage your organs, including your lungs, heart, and kidneys. ${ }^{36}$

COVID-19 complications may include Acute Respiratory Failure, Pneumonia, Acute Respiratory Distress Syndrome (ARDS), Acute 
Liver Injury, Acute Cardiac Injury, Secondary Infection, Acute Kidney Injury, Septic Shock, Disseminated Intravascular Coagulation, Blood Clots, Multisystem Inflammatory Syndrome in Children, Chronic Fatigue, Rhabdomyolysis. 3637

\section{References}

1. WHO | Coronavirus disease (COVID-2019) R\&D. https://www.who.int/blueprint/priority-diseases/keyaction/novel-coronavirus/en/. Accessed April 1, 2020.

2. Zu ZY, Jiang M Di, Xu PP, et al. Pr e ss In Pr e. 2019;2019.

3. Morens DM, Daszak P, Taubenberger JK. Escaping Pandora ' s Box Another Novel Coronavirus. 2020:1293-1295. https://doi.org/10.1056/NEJMp2002106

4. COVID-19 vs. Flu vs. Cold: Which One Do You Have? https://www.medicinenet.com/covid19_vs_flu_vs_cold/article.htm. Accessed May 19, 2021.

5. Sriram N, Mondal TR, Reddy CM, Bagh SK. I nternational J ournal of A llied M edical S ciences and C linical R esearch ( IJAMSCR ) A review on novel Corona virus. 2020; 8(1):14-20.

6. Coronavirus disease (COVID-19): Similarities and differences with influenza. https://www.who.int/emergencies/diseases/novelcoronavirus-2019/question-and-answers-hub/q-adetail/coronavirus-disease-covid-19-similarities-anddifferences-with-influenza. Accessed May 19, 2021.

7. Tang $\mathrm{X}, \mathrm{Wu} \mathrm{C}$, Li X, et al. On the origin and continuing evolution of SARS-CoV-2. doi:10.1093/nsr/nwaa036/5775463

8. Wu A, Peng Y, Huang B, et al. Genome Composition and Divergence of the Novel Coronavirus (2019-nCoV) Originating in China. Cell Host Microbe. 2020; 27(3):325-328 doi:10.1016/j.chom.2020.02.001 https://doi.org/10.1016/j.chom.2020.02.001

9. Adhikari SP, Meng S, Wu YJ, et al. Epidemiology, causes, clinical manifestation and diagnosis, prevention and control of coronavirus disease (COVID-19) during the early outbreak period: A scoping review. Infect Dis Poverty. 2020; 9(1):1-12 doi:10.1186/s40249-020-00646-x https://doi.org/10.1186/s40249-020-00646-x

10. Cascella M, Rajnik M, Cuomo A, Dulebohn SC, Di Napoli R. Features, Evaluation and Treatment Coronavirus (COVID-19). StatPearls Publishing; 2020. http://www.ncbi.nlm.nih.gov/pubmed/32150360. Accessed April 11, 2020

11. Fehr AR, Perlman S. HHS Public Access. 2016:1-23. doi:10.1007/978-1-4939-2438-7 https://doi.org/10.1007/9781-4939-2438-7

12. Coronavirus disease (COVID-19). https://www.who.int/emergencies/diseases/novelcoronavirus2019?gclid=CjwKCAjwjuqDBhAGEiwAdX2cj8RM6ZZ_t3yXvE4Ytt 8QvYT4VYylOCvVMk1H9epi7-igjTB5DI69mhoCn_4QAvD_BwE. Accessed April 17, 2021.

13. Delmas B, Laude H. Assembly of coronavirus spike protein into trimers and its role in epitope expression. J Virol. 1990;64(11):5367-5375. doi:10.1128/jvi.64.11.5367-5375.1990 https://doi.org/10.1128/jvi.64.11.5367-5375.1990

14. Connell L. Library Guides: Harvard Referencing: Lecture notes.

15. Rothan HA, Byrareddy SN. The epidemiology and pathogenesis of coronavirus disease (COVID-19) outbreak. 2020.

doi:10.1016/j.jaut.2020.102433

https://doi.org/10.1016/j.jaut.2020.102433

16. (No Title). 2020.

17. Elsevier Enhanced Reader.

https://reader.elsevier.com/reader/sd/pii/S245201442100049 2?token=7A54C695644DC2883E6C7F0ADA1E4722DD87D623E 66BAFD1296E63F1FC4B33F2627A9DD4851B1A7B68545BA9C D69677D\&originRegion=eu-west 1\&originCreation=20210501032229. Accessed May 1, 2021.
18. Covid strain: Bangalore Corona samples show 11 mutations each; virus mutating faster than before I India News - Times of India. https://timesofindia.indiatimes.com/india/covid-blurusamples-show-11-mutations-each-virus-mutating-faster-thanbefore/articleshow/81333377.cms. Accessed May 1, 2021.

19. Inside the COVID-19 mutant: The 'drift' of a virus. https://www.businesstoday.in/bt-buzz/news/inside-the-covid19-mutant-the-drift-of-a-virus/story/425695.html. Accessed May 1, 2021.

20. New Covid strain in Singapore: What we know so far about B.1.617 variant affecting children.

https://www.livemint.com/science/health/new-covid-strain-insingapore-what-we-know-so-far-about-b-1-617-variantaffecting-children-11621358293334.html. Accessed May 25, 2021

21. Callaway E. Delta coronavirus variant: scientists brace for impact. Nature. 2021; 595(7865):17-18. doi:10.1038/D41586021-01696-3 https://doi.org/10.1038/d41586-021-01696-3

22. Vaccines highly effective against B.1.617.2 variant after 2 doses GOV.UK. https://www.gov.uk/government/news/vaccineshighly-effective-against-b-1-617-2-variant-after-2-doses. Accessed July 7, 2021.

23. Bhatnagar T, Murhekar M, Soneja M, et al. Lopinavir/ritonavir combination therapy amongst symptomatic coronavirus disease 2019 patients in India: Protocol for restricted public health emergency use. Indian J Med Res. 2020; 0(0):0. doi:10.4103/ijmr.IJMR_502_20 https://doi.org/10.4103/ijmr.IJMR_502_20

24. Cao B, Wang Y, Wen D, et al. A Trial of Lopinavir-Ritonavir in Adults Hospitalized with Severe Covid-19. N Engl J Med. 2020; 382(19):1787-1799. doi:10.1056/NEJMoa2001282 https://doi.org/10.1056/NEJMoa2001282

25. Valentin F, Gurabo R. Lopinavir / Ritonavir and COVID-19. 2020 (April). doi:10.13140/RG.2.2.14844.69767

26. Roche rheumatoid arthritis drug fails to help COVID-19 patients in Italian study - Reuters. https://in.reuters.com/article/healthcoronavirus-roche-hldg/roche-rheumatoid-arthritis-drug-failsto-help-covid-19-patients-in-italian-study-idINKBN23P1WM. Accessed July 30, 2020.

27. What's new | Coronavirus Disease COVID-19. https://www.covid19treatmentguidelines.nih.gov/whats-new/. Accessed July 30, 2020.

28. Gupta AK, Parker BM, Priyadarshi V, Parker J. Cardiac Adverse Events With Remdesivir in COVID-19 Infection. Cureus. 2020 12(10). doi:10.7759/cureus.11132 https://doi.org/10.7759/cureus.11132

29. Momekov G, Momekova D. Ivermectin as a potential COVID-19 treatment from the pharmacokinetic point of view: antiviral levels are not likely attainable with known dosing regimens. Biotechnol Biotechnol Equip. 2020; 34(1):469-474. doi:10.1080/13102818.2020.1775118 https://doi.org/10.1080/13102818.2020.1775118

30. Velavan TP, Meyer CG. The COVID-19 epidemic. 2020; 25(3):278280. doi:10.1111/tmi.13383 https://doi.org/10.1111/tmi.13383

31. Pfizer and BioNTech Confirm High Efficacy and No Serious Safety Concerns Through Up to Six Months Following Second Dose in Updated Topline Analysis of Landmark COVID-19 Vaccine Study I pfpfizeruscom. https://www.pfizer.com/news/pressrelease/press-release-detail/pfizer-and-biontech-confirm-highefficacy-and-no-serious. Accessed April 17, 2021.

32. Moderna COVID-19 Vaccine Overview and Safety |CDC. https://www.cdc.gov/coronavirus/2019ncov/vaccines/different-vaccines/Moderna.html. Accessed April $17,2021$.

33. Ella R, Reddy S, Jogdand H, et al. Safety and immunogenicity clinical trial of an inactivated SARS-CoV-2 vaccine, BBV152 (a phase 2, double-blind, randomised controlled trial) and the persistence of immune responses from a phase 1 follow-up 
report. medRxiv. December 2020.

doi:10.1101/2020.12.21.20248643

https://doi.org/10.1101/2020.12.21.20248643

34. Johnson \& Johnson's Janssen COVID-19 Vaccine Overview and Safety | CDC. https://www.cdc.gov/coronavirus/2019-

ncov/vaccines/different-vaccines/janssen.html. Accessed April 17, 2021.

35. Evaluation of COVID-19 vaccine effectiveness. https://www.who.int/publications/i/item/WHO-2019-nCoV- vaccine_effectiveness-measurement-2021.1. Accessed May 16, 2021.

36. What Are the Complications of Coronavirus (COVID-19)? https://www.webmd.com/lung/coronavirus-complications\#1. Accessed May 25, 2021.

37. Certain Medical Conditions and Risk for Severe CoVID-19 Illness | CDC. https://www.cdc.gov/coronavirus/2019-ncov/needextra-precautions/people-with-medical-conditions.html. Accessed May 25, 2021 